\title{
PENANDA ASPEK SECARA MORFOLOGIS DALAM BAHASA INDONESIA
}

\author{
I Nengah Mileh \\ Universitas Warmadewa \\ milehmenuri@gmail.com
}

\begin{abstract}
ABSTRAK
Bahasa Indonesia mempunyai katagori partikel untuk menyatakan makna aspektual verbal. Partikel keaspekan tersebut dapat mendukung bermacam-macam aspek antara lain: (a) perspektif, yaitu aspek yang mengacu pada gambaran peristiwa secara keseluruhan (situasi lengkap) dan (b) Imperfektif, yaitu aspek yang menggambarkan peristiwa tidak sempurna (situasi tidak lengkap). Penelitian ini bertujuan untuk menemukan penanda aspek morfologis apa saja yang menentukan jenis aspek dalam bahasa Indonesia. Metode pengamatan dan teknik catat digunakan dalam pengumpulan data, metode deskriptif sinkronis dipakai untuk menganalis data dibantu dengan teknik induktif atau teknik deduktif, sedangkan penyajian hasil analisis digunakan metode informal, yaitu metode penyajian hasil analisis dengan menggunakan perumusan kata-kata biasa. Dalam penelitian ini ditemukan sepuluh jenis aspek, yaitu aspek duratif, prekuentif, inkoatif, perfektif, futuratif, iteratif, habituatif, momentan, spontanitas, dan indeterminatif. Penanda aspek secara morfologis yang menentukan munculnya jenis aspek dalam bahasa Indonesia adalah pembubuhan afiks (afiksasi), perulangan (reduplikasi) dan pemajemukan.
\end{abstract}

Kata kunci: aspek; bahasa; morfologi

\begin{abstract}
The Indonesian language has particle category used to explain the meaning of aspectual verbal. The aspectual particle can support various aspects, such as (a) perspective, that is the aspect referring to an overview of events as a whole (complete situation), and (b) Imperfective, namely aspects that describe imperfect events (incomplete situations). This study aims to find markers of morphological aspects that determine the types of aspects in Indonesian. Observation methods and note taking techniques were used in data collection, synchronic descriptive methods were used to analyze data assisted by inductive or deductive techniques, while the presentation of analysis results used informal methods, namely methods of presenting the results of the analysis using the formulation of words. In this study, ten types of aspects were found, namely durative, frequentative, inkoative, perfective, futurative, iterative, habituative, momentant, spontaneity, and indeterminative aspects. Morphological aspect markers that determine the appearance of the types of aspects in Indonesian are affixation (affixation), repetition (reduplication), and compounding.
\end{abstract}

Keywords: aspect, language, morphology

\section{PENDAHULUAN}

Dalam kehidupan bermasyarakat, seseorang harus bekerja sama dengan anggota masyarakat lainnya. Sebagai mahluk sosial, manusia wajib mengadakan interaksi dan bergaul dengan orang lain, baik untuk menyatakan pikirannya, perasaannya, kepentingannya dan sebagainya. Semua itu bertujuan untuk dapat memengaruhi orang lain, demi kepentingan dirinya, kepentingan kelompok atau kepentingan bersama (Mustakim, 1994: 1). Berkenaan dengan itu, ternyata bahasa mempunyai peranan yang penting dalam kehidupan manusia.

Kepentingan bahasa itu hampir melingkupi semua bidang kehidupan karena segala sesuatu yang dihayati, dialami, dirasakan, dan dipikirkan oleh seseorang, hanya dapat diketahui orang lain jika telah diungkapkan dengan bahasa. Kita tidak dapat 
membayangkan apa yang akan terjadi apabila manusia tidak memiliki bahasa. Demikian pula halnya, dengan masyarakat Indonesia yang sangat berkepentingan terhadap bahasa Indonesia untuk kepentingan dirinya, lingkungannya, dan masyarakatnya.

Perkembangan bahasa Indonesia semakin lama semakin pesat. Hal ini terbukti dengan penggunaan bahasa Indonesia yang sudah masuk pada semua lini kehidupan. Kegiatan ilmiah yang berkaitan dengan bahasa Indonesia sudah sering dilakukan baik dalam bentuk seminar, diskusi, bulan bahasa, dan sebagainya. Pembinaan dan pengembangan bahasa Indonesia sangat penting terus dilakukan, baik melalui penelitian maupun melalui kegiatan lainnya.

Bahasa Indonesia memiliki dua kedudukan yang sangat penting di negara Republik Indonesia, yaitu sebagai bahasa nasional ditetapkan tanggal 28 Oktober 1928 dan sebagai bahasa negara ditetapkan tanggal 18 Agustus 1945. Dalam kedudukan sebagai bahasa nasional bahasa Indonesia memiliki empat fungsi, yaitu (1) sebagai lambang kebanggaan nasional, (2) sebagai lambang identitas nasional, (3) sebagai alat pemersatu berbagai suku bangsa, dan (4) sebagai alat perhubungan antardaerah dan antarbudaya (Halim, 1980).

Selain berkedudukan sebagai bahasa nasional, bahasa Indonesia juga berkedudukkan sebagai bahasa negara, dalam kedudukkannya sebagai bahasa negara, bahasa Indonesia memiliki empat fungsi, yaitu (1) sebagai bahasa resmi kenegaraan, (2) sebagai bahasa resmi dilembaga-lembaga pendidikan, (3) sebagai bahasa resmi di dalam perhubungan pada tingkat nasional untuk kepentingan perencanaan dan pelaksanaan pembangunan nasional serta kepentingan pemerintahan, dan (4) sebagai alat pengembangan kebudayaan, ilmu pengetahuan, dan teknologi (Halim, 1980).

Sebagai bahasa yang hidup dan berkembang sudah tentu bahasa Indonesia banyak menerima pengaruh dari luar, baik dari bahasa daerah maupun dari bahasa asing. Hal ini disebabkan karena bahasa Indonesia tumbuh dan berkembang di antara sekian banyak bahasa daerah dan bahasa asing yang tumbuh dan berkembang di Indonesia.
Kenyataan ini menunjukkan, bahwa bahasa Indonesia bersifat terbuka dalam menerima pengaruh dari luar. Akan tetapi, ini tidak berarti bahasa Indonesia dalam menerima pengaruh dari luar tidak selektif, artinya bahasa Indonesia dalam menerima pengaruh tersebut disesuaikan dengan aturan yang berlaku dalam bahasa Indonesia.

Bahasa Indonesia sebagai objek penelitian telah banyak dibicarakan, baik berupa makalah, skripsi, tesis, maupun disertasi. Demikian juga halnya dengan masalah aspek dalam bahasa Indonesia, sudah banyak dibicarakan dalam berbagai buku. Akan tetapi, penelitian secara mengkhusus mengenai masalah ini masih perlu dilakukan.

Berdasarkan latar belakang di atas, maka penelitian secara mengkhusus mengenai masalah penanda aspek dalam bahasa Indonesia perlu dilakukan, agar dapat diperoleh informasi yang lebih lengkap mengenai masalah ini. Untuk memeroleh ketajaman analisis dalam penelitian ini, dibatasi pula masalah yang diteliti. Adapun masalah yang akan diteliti pada kesempatan ini adalah sebagai berikut.

1. Apa yang dimaksud dengan aspek dan bagaimana klasifikasi aspek tersebut dalam bahasa Indonesia?

2. Apa saja penanda aspek secara morfologis yang ada dalam bahasa Indonesia?

\section{METODE}

Metode penelitian yang baik harus sesuai dengan objek penelitiannya. Metode sebagai cara kerja haruslah dijabarkan sesuai dengan alat dan sifat alat yang digunakan. Jabaran metode yang sesuai dengan alat dan sifat alat yang digunakan selanjutnya disebut dengan teknik (Sudaryanto, 1985:26). Dalam penelitian ini, ada tiga metode dan teknik yang digunakan, yaitu sebagai berikut.

\section{Metode dan Teknik Pengumpulan Data}

Pengumpulan data dalam penelitian ini dilakukan dengan metode observasi/pengamatan. Pengamatan terhadap bentuk pemakaian bahasa Indonesia lisan dan juga bahasa tulisan. Metode ini dibantu dengan teknik pencatatan. Di samping itu, juga digunakan teknik alitisasi dengan alasan penulis sendiri juga sebagai penutur bahasa 
Indonesia sekaligus juga bertindak sebagai sampel.

\section{Metode dan Teknik Pengolahan Data}

Setelah data terkumpul, langkah selanjutnya adalah tahap pengolahan/analisis data. Dalam tahapan pengolahan data ini digunakan metode deskriptif sinkronis, yaitu menganalisis data apa adanya secara objektif dengan data yang bersifat kekinian.

\section{Metode dan Teknik Penyajian Hasil Analisis}

Metode yang digunakan dalam penyajian hasil analisis adalah metode informal. Metode informal adalah metode penyajian hasil analisis dengan menggunakan perumusan kata-kata biasa (Sudaryanto, 1982: 16). Metode ini dibantu dengan teknik induktif, yaitu suatu cara penyajian dengan mengemukakan hal-hal yang bersifat khusus, kemudian dibuat simpulan yang bersifat umum

\section{PEMBAHASAN}

Dalam bab ini akan dibahas mengenai pengertian, klasifikasi aspek, dan aspek apa saja yang ada dalam bahasa Indonesia. Uraian secara rinci dapat diperhatikan berikut ini.

\section{Pengertian dan Klasifikasi Aspek Dalam Bahasa Indonesia}

1. Pengertian Aspek Dalam Bahasa Indonesia

Ada beberapa pendapat mengenai pengertian aspek dalam bahasa Indonesia. Dalam penelitian ini, yang diacu adalah pendapat dari Fatimah Djayasoedarma dalam bukunya yang berjudul "Aspek, Kala/Adverbia Temporal, dan Modus" (1985), yang menyatakan, bahwa bahasa Indonesia mempunyai katagori partikel untuk menyatakan makna aspektual verbal. Partikel keaspekan tersebut dapat mendukung bermacam-macam aspek antara lain: (a) Perspektif, yaitu aspek yang mengacu pada gambaran peristiwa secara keseluruhan (situasi lengkap): awal, tengah, dan akhir). (b) Imperfektif, yaitu aspek yang menggambarkan situasi kontinuatif duratif (progresif), termasuk habituatif (takprogresif) dengan kelompok frekuentif dan takprekuentif (Djayasoedarma, 1985).

Berdasarkam partikel keaspekan tersebut dapat ditentukan, bahwa bahasa Indonesia memiliki katagori aspek perfektif dan imperfektif. Jadi menurutnya, aspek adalah struktur temporal intern suatu situasi. Lebih lanjut dikatakan, bahwa situasi yang dimaksud dapat berupa keadaan, peristiwa, dan proses.

2. Klasifikasi Aspek Dalam Bahasa Indonesia

Seperti telah dijelaskan di atas, aspek adalah struktur temporal intern suatu situasi. Situali tersebut dapat berupa keadaan, peristiwa, dan proses. Di dalam suatu kalimat, keadaan, peristiwa, dan proses bisa dipandang sedang terjadi, akan terjadi, sudah terjadi, terjadi secara tiba-tiba, dan sebagainya bergantung pada sudut pandang atau cara memandang situasi tersebut. Berdasarkan pengertian itu, maka uraian selanjutnya akan dibicarakan tentang klasifikasi aspek dalam bahasa Indonesia. Klasifikasi itu disesuaikan dengan keadaan, peristiwa, dan proses yang digambarkan dalam suatu kalimat.

Sebelum membicarakan klasifikasi aspek dalam bahasa Indonesia, terlebih dahulu akan diberikan beberapa contoh kalimat sebagai bahan analisis. Perhatikan kalimat-kalimat berikut ini.

(1) Perum Pos dan Giro sedang mengadakan penjajagan terhadap pengenaan sanksi bagi surat yang tidak berisi kode pos alamat surat yang dituju.

(2) Pasar tradisional sering dikunjungi oleh ibuibu PKK.

(3) Ia mulai dilatih sejak umur tiga tahun.

(4) Anggota DPR RI telah mengadakan sidang paripurna.

(5) OPEC akan mengadakan pertemuan di Wina.

(6) Ia berkata sembari menepuk-nepuk dadanya.

(7) Pekarangan yang biasa didatangi burungburung adalah pekarangan yang tanamannya tinggi-tinggi.

(8)Diambilnya surat itu dari sakunya, lalu dibacanya.

Kalimat-kalimat di atas masing-masing menggambarkan keadaan, peristiwa, dan proses. Perberbedaan pandangan terhadap keadaan, peristiwa, dan proses dalam kalimatkalimat di atas menyebabkan adanya berbagai jenis aspek. Hal itu dapat dijelaskan pada uraian berikut ini. 
Pada kalimat nomor (1) di atas menggambarkan suatu kejadian atau peristiwa yaitu mengadakan penjajagan terhadap pengenaan sanksi bagi surat yang tidak berisi kode pos alamat surat yang dituju. Kejadian yang digambarkan dalam kalimat tersebut sedang berlangsung, pada waktu kalimat itu dituturkan. Hal ini ditandai dengan kata sedang yang menerangkan kejadian itu. Selanjutnya kalimat yang menggambarkan keadaan, pristiwa, dan proses yang sedang terjadi digolongkan ke dalam jenis aspek duratif/inkompletif.

Peristiwa atau kejadian yang digambarkan dalam kalimat nomor (2) di atas adalah peristiwa atau kejadian tentang pasar tradisional sering dikunjungi oleh Ibu-ibu PKK. Peristiwa atau kejadian itu terjadi beberapa kali atau berulang-ulang, tetapi tidak terusmenerus. Hal ini dinyatakan dengan kata sering. Aspek kalimat yang menggambarkan keadaan, pristiwa, dan proses yang demikian dimasukkan ke dalam jenis aspek frekuentatif.

Kalimat selanjutnya adalah kalimat nomor (3). Kalimat ini menggambarkan suatu peristiwa atau kejadian dilatih, yang dinyatakan dengan kata kerja dilatih. Peristiwa atau kejadian yang digambarkan tersebut mulai terjadi, yang ditandai dengan kata mulai. Apabila dilihat dari segi aspeknya kalimat yang menggambarkan suatu keadaan, pristiwa, dan proses yang mulai terjadi dimasukkan ke dalam jenis aspek inkoatif.

Kalimat nomor (4) di atas menggambarkan peristiwa atau keadaan DPR RI telah mengadakan sidang paripurna. Peristiwa atau kejadian yang digambarkan tersebut sudah terjadi atau sudah selesai pada saat kalimat itu dituturkan. Hal ini diterangkan oleh kata telah yang menerangkan kata mengadakan. Selanjutnya aspek kalimat yang menggambarkan suatu keadaan, pristiwa, dan proses yang sudah terjadi dimasukkan ke dalam aspek perfektif.

Kalimat nomor (5) di atas menyatakan suatu peristiwa atau kejadian yang akan terjadi. Maksudnya, mengadakan pertemuan di Wina yang merupakan peristiwa atau kejadian yang digambarkan dalam kalimat itu akan terjadi pada waktu kalimat itu dituturkan. Hal ini ditunjukkan dengan kata akan, yang menandai bahwa peristiwa atau keadaan yang dinyatakan dengan kata kerja mengadakan akan terjadi. Aspek kalimat yang menyatakan suatu keadaan, pristiwa, dan proses yang demikian digolongkan ke dalam aspek futuratif.

Pada kalimat nomor (6) juga termasuk kalimat yang beraspek, karena menggambarkan suatu peristiwa atau kejadian. Peristiwa atau kejadian yang digambarkan adalah menepuknepuk dada yang dilakukan oleh seseorang (ia). Kejadian itu dinyatakan dengan kata ulang menepuk-nepuk, yang berarti bahwa peristiwa atau kejadian itu dilakukan secara berulangulang tanpa putus-putus. Atau dengan kata lain, peristiwa atau kejadian itu terjadi secara terusmenerus tanpa berhenti. Aspek kalimat yang menggambarkan suatu keadaan, pristiwa, dan proses yang demikian digolongkan ke dalam jenis aspek iteratif.

Peristiwa atau kejadian yang digambarkan dalam kalimat nomor (7) di atas adalah pekarangan yang dikunjungi burung-burung. Kejadian atau peristiwa itu merupakan kebiasaan bagi burung-burung untuk mengunjungi pekarangan yang tanamannya tinggi-tinggi. Hal ini diterangkan dengan kata biasa. Aspek kalimat yang menggambagrkan suatu keadaan, pristiwa, dan proses yang merupakan kebiasaan digolongkan ke dalam aspek habituatif.

Seperti halnya beberapa kalimat di atas, kalimat nomor (8) juga termasuk kalimat yang beraspek, karena kalimat tersebut juga menggambarkan suatu peristiwa atau kejadian. Dalam kalimat tersebut terjadi peralihan kejadian dari satu kejadian ke kejadian lain. Dengan demikian, kejadian mengambill dan membaca surat yang digambarkan dalam kalimat tersebut, dilakukan secara beruturutturut dalam waktu yang singkat. Aspek yang menggambarkan suatu peristiwa atau kejadian yang terjadi dalam waktu yang singkat atau sebentar, baik yang terjadi sekali maupun berturut-turut digolongkan ke dalam aspek momentan.

Di samping beberapa jenis aspek yang telah disebutkan di atas, masih ada jenis aspek yang lain. Aspek jenis ini dapat dijelaskan dengan kalimat berikut.

(9) Orang tua itu menyeberang jalan tiba-tiba. (10) Setiap hari anak itu melamun-lamun saja.

Gambaran peristiwa atau kejadian yang terdapat dalam kalimat nomor (9) adalah ketika 
orang tua itu menyeberang jalan tiba-tiba. Kejadian atau peristiwa itu terjadi secara tibatiba atau tanpa disangka-sangka. Hal ini dinyatakan dengan kata tiba-tiba. Aspek kalimat yang menyatakan suatu peristiwa atau kejadian yang terjadi secara tiba-tiba atau tanpa disangka-sangka digolongkan ke dalam jenis aspek spontanitas.

Kalimat nomor (10) juga termasuk kalimat beraspek, yang menggambarkan suatu peristiwa atau kejadian melamun. Peristiwa atau kejadian itu dilakukan secara santai, seenaknya, atau tanpa tujuan tertentu. Hal ini dinyatakan dengan kata melamun. Aspek yang menggambarkan suatu peristiwa atau kejadian yang dilakukan secara santai atau seenaknya tersebut digolongkan ke dalam jenis aspek indeterminatif.

Berdasarkan analisis beberapa kalimat di atas, dapat disimpulkan aspek dalam bahasa Indonesia dapat diklasifikasikan ke dalam beberapa jenis. Klasifikasi aspek yang dimaksud adalah sebagai berikut.

1) Aspek duratif, yaitu aspek yang menyatakan suatu keadaan, peristiwa, dan proses yang sedang berlangsung atau sedang terjadi. Aspek ini juga disebut aspek inkompletif.

2) Aspek frekuentatif, yaitu aspek yang menyatakan suatu keadaan, peristiwa, dan proses yang terjadi beberapa kali secara terputus-putus. Atau dengan kata lain, aspek ini menggambarkan suatu peristiwa atau kejadian yang terjadi beberapa kali tetapi tidak terus-menerus.

3) Aspek inkoatif, yaitu aspek yang menyatakan suatu keadaan, peristiwa, dan proses yang mulai terjadi.

4) Aspek perfektif, yaitu aspek yang menyatakan suatu keadaan, peristiwa, dan proses yang telah terjadi atau sudah selesai.

5) Aspek futuratif, yaitu aspek yang menyatakan suatu keadaan, peristiwa, dan proses yang akan terjadi atau akan berlangsung.

6) Aspek iteratif, yaitu aspek yang menyatakan suatu keadaan, peristiwa, dan proses yang terjadi berulang-ulang tanpa putus-putus atau terus-menerus.
7) Aspek habituatif, yaitu aspek yang menyatakan suatu keadaan, peristiwa, dan proses yang terjadi karena kebiasaan.

8) Aspek momentan, yaitu aspek yang menyatakan suatu keadaan, peristiwa, dan proses yang terjadi sekali ataupun yang terjadi secara berturut-turut dalam waktu yang singkat atau sebentar.

9) Aspek spontanitas, yaitu aspek yang menyatakan suatu keadaan, peristiwa, dan proses yang terjadi secara tiba-tiba atau tanpa disangka-sangka.

10) Aspek indeterminatif, yaitu aspek yang menyatakan suatu keadaan, peristiwa, dan proses yang dilakukan secara santai, seenaknya, atau tanpa tujuan tertentu.

\section{Penanda Aspek Secara Morfologis Dalam Bahasa Indonesia}

Setiap bahasa di dunia mempunyai caracara tersendiri untuk menandai aspeknya (Samsuri, 1985: 251). Misalnya, ada yang memakai unsur-unsur morfologis, yaitu dengan penanda afiksasi yang berbeda dan ada pula yang menggunakan kata-kata tertentu untuk memberikan penanda aspek tersebut.

Morfologi merupakan tataran dalam ilmu bahasa yang membicarakan seluk beluk kata. Tataran ini mempunyai satuan terkecil sebagai batas pembatasannya yang disebut morfem. Morfem ini mempunyai makna tertentu dan tidak dapat dibagi menjadi bagian-bagian lebih kecil lagi yang bermakna. Sebagai satuan terkecil, morfem merupakan konstituen satuansatuan gramatikal yang lebih besar, seperti kata, frase, dan kalimat.

Kata sebagai satuan gramatikal terbesar dalam bidang morfologi, bisa terdiri atas satu morfem dan ada pula yang terdiri atas beberapa morfem. Dalam bahasa Indonesia ada tiga proses morfologis, yaitu proses pembubuhan afiks, proses perulangan, dan proses pemajemukan. Masing-masing proses ini akan dibahas berikut ini.

\section{Proses Pembubuhan Afiks (Afiksasi)}

Afiksasi adalah proses pembubuhan afiks pada suatu satuan baik berupa bentuk tunggal maupun bentuk kompleks untuk membentuk kata. Afiks adalah satuan-satuan gramatik terikat dalam suatu kata yang merupakan unsure bukan kata dan bukan pokok kata yang 
memiliki kesanggupan melekat pada satuansatuan lain untuk membentuk kata atau pokok kata (Ramlan. M, 1983: 48)

Afiks, apabila dilihat dari segi melekat pada bentuk dasar dapat dibedakan menjadi prefiks, yaitu afiks yang melekat pada bagian depan bentuk dasar; infiks, yaitu afiks yang melekat ditengah bentuk dasar; dan sufiks, yaitu yang melekat pada akhir bentuk dasar. Di samping itu, juga dikenal bentuk konfiks, yaitu gabungan dua macam afiks yang merupakan morfem terbagi, tetapi bersama-sama mempunyai satu fungsi dan membentuk satu arti.

Sehubungan dengan pembicaraan aspek dalam bahasa Indonesia, maka afiks yang akan dibicarakan adalah afiks yang dapat membentuk kata yang menyatakan keadaan, peristiwa, dan proses. Beberapa afiks yang menyatakan aspek dapat dilihat pada kalimatkalimat berikut.

11) Berita buruk itu meluas dari mulut ke mulut.

12) Peristiwa tragis menyebabkan lima orang tewas terbakar.

13) Kambing itu melahirkan anak yang cacat.

14) Pencuri itu dipukuli karena melakukan kejahatan di pasar.

15) Para penunpang kapal itu berlompatan menyelamatkan diri.

Kata-kata yang bergaris bawah pada kalimat-kalimat di atas berfungsi sebagai predikat, yang menyatakan keadaan, peristiwa, dan proses. Apabila dilihat dari bentuknya, masing-masing kata tersebut termasuk kata kompleks yang terdiri atas beberapa morfem sebagai unsurnya. Seperti kata meluas, terbakar, melahirkan, dipukuli, dan berlompatan. Kata-kata di atas dibentuk melalui afiksasi. Hal ini dapat dijelaskan sebagai berikut.

Kata meluas dibentuk dari bentuk dasar $\underline{\text { luas ditambah prefiks meN- dan kata terbakar }}$ bentuk dasarnya bakar ditambah prefiks ter-. Kata selanjutnya adalah kata melahirkan, dipukuli, dan berlompatan. Ketiga kata ini terjadi melalui dua kali proses pembentukan. Artinya, kata melahirkan berasal dari bentuk dasar lahir ditambah sufiks _kan membentuk kata lahirkan. Kemudian kata lahirkan mendapat prefiks meN- sehingga menjadi melahirkan. Kata dipukuli dibentuk dari bentuk dasar pukul, mendapat penambahan sufiks $\underline{-i}$ sehingga terbentuk kata pukuli. Kemudian kata ini ditambah prefiks di- menjadi dipukuli. Begitu juga halnya dengan kata berlompatan. Kata ini dibentuk dari bentuk dasar lompat, dan ditambah sufiks -an menjadi lompatan. Kata lompatan selanjutnya mendapat prefiks bersehingga terbentuk kata berlompatan.

Berdasarkan uraian tentang pembentukan masing-masing kata di atas, dapat diketahui ada beberapa afiks yang dapat membentuk katakata yang menyatakan keadaan, peristiwa, dan proses. Afiks yang dimaksud itu adalah meN-, ter-, -kan, di-, dan ber-an.

\section{a. Prefiks meN-}

Pada kalimat (11) di atas menyatakan suatu proses, yaitu meluasnya berita buruk dari mulut ke mulut. Hal itu dinyatakan dengan bentuk kata kerja meluas, yang dibentuk dari bentuk dasar luas dan mendapat tambahan prefiks meN-. Akibatnya, timbul makna baru yang menyatakan 'menjadi seperti keadaan yang tersebut pada bentuk dasar' atau menyatakan makna 'proses'. Dengan demikian, kejadian meluas yang digambarkan dalam kalimat di atas sedang terjadi. Kalimat yang menggambarkan suatu kejadian yang demikian dimasukkan ke dalam jenis aspek duratif. Atau dengan kata lain prefiks meN- yang menyatakan makna 'proses' dapat menandai jenis aspek duratif.

Di samping menyatakan makna 'proses', prefiks meN- juga dapat menyatakan makna lain. Hal ini dapat dijelaskan dengan kalimat berikut.

16) Dari pantai kelihatan perahu-perahu nelayan itu menepi.

17) Wisatawan itu memarkir mobilnya di depan hotel.

Kalimat nomor (16) di atas menggambarkan suatu peristiwa atau kejadian menepi yang dinyatakan dengan bentuk kata kerja menepi. Kata kerja ini terdiri atas bentuk dasar tepi ditambah prefiks meN-. Akibat penambahan prefiks_meN- itu, timbul makna baru yang menyatakan 'menuju ke tepi' atau 'menuju ke (seperti tersebut pada bentuk dasar)'. Hal ini dapat dikatakan sebagai penanda aspek duratif.

Kejadian yang digambarkan dalam kalimat nomor (17) adalah wisatawan itu memarkir mobilnya di depan hotel. Hal ini dinyatakan 
dengan kata kerja memarkir. Kata kerja ini dibentuk dari bentuk dasar parkir dan ditambah prefiks meN-. Pertemuan kedua bentuk itu menimbulkan makna baru atau makna gramatikal yang menyatakan 'melakukan pekerjaan seperti yang tersebut dalam bentuk dasar'. Apabila dilihat dari aspek kejadiannya, peristiwa itu digambarkan dengan kata memarkir adalah tidak tentu. Dengan demikian, prefiks meN- yang bermakna 'melakukan pekerjaan seperti yang tersebut pada bentuk dasar', tidak menandai jenis aspek tertentu.

Berdasarkan analisis di atas, maka dapat diketahui, bahwa prefiks meN- yang menandai jenis aspek tertentu adalah prefiks meN- yang bermakna 'menjadi seperti tersebut pada bentuk dasar' atau makna proses dan makna 'menuju tempat yang tersebut pada bentuk dasar'. Aspek yang ditandai adalah aspek duratif, yaitu aspek yang menggambarkan suatu peristiwa atau kejadian yang sedang terjadi.

\section{b. Prefiks ter-}

Kalimat nomor (12) di atas menggambarkan suatu peristiwa tragis yang menyebabkan lima orang tewas terbakar. Kejadian itu dinyatakan dengan kata kerja terbakar. Kata kerja terbakar dibentuk dari bentuk dasar bakar dan ditambah prefiks ter -. Bentuk dasar bakar sebelum bertemu dengan prefiks ter- sudah mempunyai makna leksikal. Akan tetapi, setelah terjadi pertemuan dengan prefiks ter-, timbul makna baru yang menyatakan bahwa "peristiwa atau kejadian seperti yang terjadi pada bentuk dasar sudah selesai dilakukan'. Dengan demikian, peristiwa atau kejadian yang digambarkan dalam kalimat nomor (12) sudah selesai pada waktu kalimat itu dituturkan. Apabila dilihat dari segi aspeknya, kalimat yang menggambarkan suatu peristiwa atau kejadian yang sudah selesai atau sudah terjadi digolongkan ke dalam jenis aspek prefektif. Jadi, prefiks ter- yang mempunyai makna bahwa "peristiwa atau kejadian yang tersebut pada bentuk dasar sudah selesai' dapat menandai jenis aspek perfektif.

Disamping prefiks ter- yang bermakna seperti tersebut di atas, dalam pemakaian bahasa Indonesia dapat ditemukan makna prefiks ter- yang lain. Hal ini dapat dilihat dalam kalimat berikut.

18) Kami terbangun secara tiba-tiba.
19) Tangannya tertusuk jarum ketika menjahit baju untuk adik.

Kalimat nomor (18) di atas menggambarkan suatu peritiwa atau kejadian, bahwa kami terbangun secara tiba-tiba. Hal ini dinyatakandengan kata kerja terbangun. Kata kerja ini dibentuk dari bentuk dasar bangun dan mendapat tambahan prefiks ter-. Akibat pertemuan itu menimbulkan makna baru yang menyatakan 'peristiwa atau kejadian yang tersebut pada bentuk dasar terjadi secara tibatiba. Jadi, prefiks ter- yang membentuk kata kerja terbangun menyatakan makna gramatikal 'tiba-tiba'. Selanjutnya, kalimat yang menggambarkan peristiwa atau kejadian yang demikian apabila dilihat dari segi aspeknya dimasukkan ke dalam aspek spontanitas. Dengan demikian, prefiks ter- yang menyatakan makna 'tiba-tiba' dapat menandai aspek spontanitas.

Kalimat berikutnya adalah kalimat nomor (19). Kalimat ini menggambarkan suatu peristiwa atau kejadian tentang tangan yang tertusuk jarum. Peristiwa atau kejadian itu dinyatakan dengan kata kerja tertusuk. Kata kerja ini ini dibentuk dari bentuk dasar tusuk dan mendapat prefiks ter-. Pertemuan bentuk dasar tusuk dengan prefiks ter- itu menimbulkan makna baru yang menyatakan 'perbuatan yang tersebut pada bentuk dasar terjadi karena tidak disengaja'. Jadi, prefiks teryang membentuk kata kerja tertusuk mempunya makna 'tidak sengaja'. Apabila dilihat dari segi aspeknya, peristiwa atau kejadian yang digambarkan dalam kalimat di atas sudah terjadi. Oleh karena itu, kalimat nomor (19) di atas termasuk dalam jenis aspek perfektif. Dengan kata lain, prefiks ter- yang bermakna 'tidak sengaja' dapat menandai aspek perfektif.

Berdasarkan uraian beberapa kalimat di atas, dapat diketahui bahwa prefiks ter- yang menandai jenis aspek tertentu adalah prefiks ter- yang menyatakan makna 'perbuatan seperti yang tersebut pada bentuk dasar sudah selesai', menyatakan makna 'perbuatan yang terjadi karena tidak disengaja', dan yang menyatakan 'perbuatan secara tiba-tiba'. Aspek yang ditandai adalah aspek perfektif dan aspek spontanitas.

c. Sufiks -kan 
Peristiwa atau kejadian yang digambarkan dalam kalimat nomor (13) adalah lahirnya anak kambing yang cacat. Hal ini digambarkan dengan bentuk kata kerja melahirkan. Seperti telah diuraiakan di depan, kata ini dibentuk dari bentuk dasar lahir, ditambah sufiks -kan dan prefiks meN-. Sufiks -kan yang melekat pada bentuk dasar lahir mempunyai makna "menyatakan kejadian yang tersebut pada bentuk dasar terjadi karena sesuatu' atau menyatakan 'perbuatan merupakan peristiwa yang sudah terjadi atau sudah selesai' pada waktu kalimat itu dituturkan. Dengan kata lain, sufiks -kan yang menyatakan makna 'kausatif' dapat menandai jenis aspek tertentu. Jenis aspek yang dimaksud adalah aspek perfektif. Contoh kalimat yang lain yang menyatakan aspek perfekti, yaitu sebagai berikut.

20) Bangunan yang besar itu menghabiskan dana yang cukup besar.

21) Tanah longsor yang terjadi kemarin menewaskan puluhan orang.

\section{d. Sufiks -i}

Kalimat nomor (14) di depan juga merupakan kalimat beraspek, yang menggambarkan suatu peristiwa atau kejadian tentang pemukulan terhadap seorang pencuri. Kejadian itu dilukiskan dengan kata kerja dipukuli. Kata kerja ini dibentuk dari bentuk dasar pukul, kemudian mendapat sufiks $\underline{-i}$ sehingga terbentuklah kata pukuli dan ditambah dengan prefiks di- menjadi dipukuli. Setelah mendapatkan tambahan sufiks -i, maka timbul makna baru yang menyatakan bahwa peristiwa atau kejadian yang tersebut pada bentuk dasar dilakukan berulang-ulang secara berturur-turut. Aspek kalimat yang menggambarkan suatu peristiwa atau kejadian yang demikian digolongkan ke dalam jenis aspek iteratif. Jadi aspek iterative dalam kalimat (14) di atas ditandai dengan sufiks -i. Beberapa kalimat yang juga memiliki aspek iteratif dapat dilihat pada contoh kalimat berikut.

22) Ayah duduk-duduk di pantai sambil memandangi burung-burung yang terbang tinggi.

23) Buah jambu pak Karta_dilempari oleh anak-anak.

e. Konfiks ber-an
Kalimat selanjutnya adalah kalimat nomor (15). Peristiwa atau kejadian yang digambarkan dalam kalimat ini adalah penumpang kapal yang berlompatan, yang dinyatakan dengan kata kerja berlompotan. Kata ini dibentuk dari bentuk dasar lompat, ditambah dengan konfiks ber-an. Akibat pertemuan bentuk dasar dengan konfiks tersebut timbul makna baru, yaitu ' menyatakan perbuatan yang tersebut pada bentuk dasar dilakukan berulang-ulang tanpa putus-putus". Aspek kalimat yang menggambarkan suatu peristiwa atau kejadian yang demikian termasuk jenis aspek iteratif. Jadi, aspek iteratif dalam kalimat nomor (15) di tandai oleh konfiks ber-an.

Contoh:

24) Air matanya bercucuran mendengar berita kematian temannya.

25) Setelah mendengar bel sekolah berbunyi, anak-anak SD itu berlarian ke luar kelas.

Dalam pemakaian bahasa Indonesia, dijumpai pemakaian konfiks ber-an yang lain. Hal ini dapat dilihat pada kalimat berikut ini.

26) Dua buah bus bertabrakan yang mengakibatkan lima orang tewas seketika.

27) Dalam perang Irak-Iran korban berjatuhan di kedua belah pihak.

Kata bertabrakan dalam kalimat (26) di atas, dibentuk dari bentuk dasar tabrak kemudian ditambah konfiks ber-an. Penambahan konfiks ber-an pada bentuk dasar menimbulkan makna baru yang menyatakan 'saling' atau makna 'resiprokatif'. Apabila dilihat dari aspeknya, peristiwa atau kejadian yang digambarkan dalam kalimat di atas sudah terjadi, sehingga dapat dimasukkan ke dalam jenis aspek perfektif. Dengan demikian, konfiks ber-an yang menyatakan makna 'saling' dapat menandai jenis aspek perfektif.

Dalam kalimat nomor (27) juga terdapat kata yang mengandung pemakaian konfiks beran. Kata tersebut adalah berjatuhan, yang terbentuk dari bentuk dasar jatuh. Akibat penambahan konfiks ber-an pada bentuk dasar tersebut, maka timbul makna baru yang menyatakan 'banyak seperti yang tersebut pada bentuk dasar'. Dengan kata lain, kata berjatuhan dalam kalimat di atas berarti 'banyak jatuh'. Gambaran peristiwa atau kejadian yang dinyatakan dengan kata itu tidak tentu, sehingga kalimat tersebut digolongkan ke dalam kalimat yang beraspek tidak tentu. 
Jadi, konfiks ber-an yang mengandung arti 'banyak' tidak menandai jenis aspek tertentu.

Berdasarkan uraian di atas, maka konfiks ber-an yang menandai jenis aspek tertentu adalah menyatakan makna 'melakukan perbuatan seperti pada bentuk dasar secara terus menerus' dan yang menyatakan makna 'saling'. Aspek yang ditandai, masing-masing adalah aspek iteratif dan aspek prefektif.

\section{Proses Perulangan (Reduplikasi)}

Di depan telah diesebutkian, bahwa reduplikasi merupakan salah satu proses morfologis dalam bahasa Indonesia yang juga berfungsi sebagai penanda aspek. Reduplikasi adalah proses perulangan satuan gramatik baik seluruhnya maupun sebagian, baik dengan variasi fonem maupun tidak (Ramlan, 1983:55). Atau dengan kata lain, reduplikasi adalah proses untuk menghasilkan kata ulang. Hasil proses pengulangan ini disebut kata ulang, sedangkan bentuk yang diulang disebut bentuk dasar. Bentuk dasar adalah bentuk yang menjadi dasar pembentukan yang lebih besar.

Berdasarkan cara mengulang bentuk dasarnya, dapat ditentukan jenis-jenis perulangan. Di dalam bahasa Indonesia ada beberapa jenis perulangan seperti perulangan seluruhnya, perulangan sebagian, perulangan yang berkombinasi dengan perubahan afiks, dan perulangan yang disertai dengan perubahan fonem.Masing-masing jenis perulangan itu mendukung makna yang berbeda-beda, Makna yang timbul antara lain menyatakan banyak, menyerupai, perbuatan seperti yang tersebut pada bentuk dasar dilakukan oleh dua orang dan saling mengenai, dan menyatakan makna agak (Ramlan 1983:61)

Sehubungan dengan pembicaraan penanda aspek dalam bahasa Indonesia, ditemukan beberapa jenis kata ulangyang dapat menandai jenis aspek tertentu. Untuk mengetahui jenis kata ulang itu, perhatika beberapa kalimat di bawah ini.

28) Di dalam mobil terlihat ibunya melambailambaikan tangan dengan manisnya.

29) Acara kumpul-kumpul ditempat itu mengundang perhatian banyak orang.

30) Mereka sering bersurat-suratan walaupun sering bertemu.

Kalimat nomor (28) di atas menggambarkan peristiwa atau kejadian melambaikan tangan yang dinyatakan dengan kata melambai-lambaikan. Kata ulang ini dibentuk dari bentuk dasar melambaikan, dan mengalami proses perulangan sebagian. Setelah mengalami proses perulangan, maka makna yang didukung menyatakan bahwa "peristiwa atau kejadian seperti yang tersebut pada bentuk dasar dilakukan secara berulang-ulang'. Dengan demikian, kalimat di atas dapat dimasukkan ke dalam kalimat yang beraspek iteratif. Hal ini disebabkan oleh karena peristiwa atau kejadian yang digambarkan dalam kalimat itu terjadi secara berulang-ulang. Akan tetapi, dalam kenyataannya tidak selalu mudah membedakan suatu peristiwa atau kejadian yang berulang-ulang dengan kejadian atau peristiwa yang terjadi terus-menerus tanpa berhenti. Sebab kenyataannya, peristiwa atau kejadian yang dikatakan terjadi berulang-ulang bisa terjadi terputus-putus. Contoh lain dapat dilihat pada kalimat berikut.

28a) Karena udara sejuk, kawan saya terkantukkantuk dibuatnya.

Peristiwa atau kejadian yang digambarkan dala kalimat nomor (29) di atas adalah peristiwa atau kejadian kumpul, yang dinyatakan dengan kata ulang kumpul-kumpul. Kata ulang ini dibentuk dari bentuk dasar kumpul dan diulang secara keseluruhan (utuh). Setelah mengalami proses perulangan, makna yang didukung menyatakan 'perbuatan seperti yang tersebut pada bentuk dasar dilakukan secara santai atau seenaknya'. Selanjutnya, aspek kalimat yang menggambarkan peristiwa atau kejadian yang demikian termasuk aspek indeterminatif. Atau dengan kata lain, kata ulang yang menyatakan makna 'perbuatan seperti yang tersebut pada bentuk dasar dilakukan secara santai atau seenaknya', dapat dikatakan menandai aspek indeterminatif. Contoh lain dapat dilihat pada kalimat berikut ini.

29a) Ayah dan Ibu duduk-duduk di beranda muka.

29b) Mereka tidur-tiduran di pantai yang berpasir putih.

Kalimat berikutnya adalah kalimat nomor (30) di atas. Kalimat ini juga menggambarkan suatu peristiwa atau kejadian yang dinyatakan dengan kata ulang bersurat-suratan. Kata ulang ini dibentuk dari bentuk dasar surat, kemudian mengalami proses perulangan yang berkombinasi dengan penambahan afiks. 
Makna yang didukung oleh kata ulang itu menyatakan makna 'resiprokal atau berbalasan'. Jadi, peristiwa atau kejadian itu dilakukan oleh dua pihak dan saling mengenai. Apabila dilihat dari segi macam perbuatannya, peristiwa atau kejadian itu dilakukan berulangulang. Untuk membedakan dengan kejadian yang berulang-ulang secara terus-menerus, maka dieksplisitkan dengan kata sering. Dengan demikian, peristiwa atau kejadian yang digambarkan menjadi berulang-ulang tetapi terputus-putus. Selanjutnya, aspek kalimat yang menggambarkan peristiwa atau kejadian yang demikian dimasukkan ke dalam aspek prekuentatif. Jadi, dalam hal ini aspek prekuentatif tidak saja ditandai oleh kata ulang yang menyatakan 'resiprokal', tetapi juga ditandai dengan bantuan kata penunjuk aspek sering. Contoh lain dapat dilihat pada kalimat berikut.

30a) Ibu itu berlari ke tempat anaknya yang sedang berpukul-pukulan dengan temannya.

Berdasarkan uraian di atas, dapat diketahui beberapa jenis kata ulang yang dapat menandai aspek tertentu. Kata ulang itu adalah kata ulang yang menyatakan makna 'perbuatan seperti tersebut pada bentuk dasar secara berulangulang, "perbuatan seperti yang tersebut pada bentuk dasar dilakukan secara santai dan seenaknya, dan yang menyatakan makna 'resiprokal'. Jenis aspek yang ditandai oleh masing-masing kata ulang tersebut adalah aspek iteratif, aspek indeterminatif, dan aspek frekuentatif.

\section{Proses Pemajemukan}

Selain melalui proses afiksasi dan perulangan, kata dalam bahasa Indonesia juga dapat dibentuk melalui proses pemajemukan. Kata yang terbentuk sebagai akibat dari proses pemajemukan disebut kata majemuk. Kata majemuk dalam bahasa Indonesia dapat dibagi berdasarkan beberapa dasar pembagian. Misalnya, kata majemuk berdasarkan jenis morfem yang menjadi unsurnya, berdasarkan jenis kata yang menjadi unsurnya, berdasarkan hubungan antarunsurnya, dan berdasarkan susunan unsurnya ( Nazir Thoir, 1985:77).

Sehubungan dengan pembicaraan penanda aspek secara morfologis dalam bahasa Indonesia, ditemukan kata majemuk yang dapat menandai jenis aspek tertentu dalam bahasa Indonesia. Untuk mengetahui jenis aspek yang ditandai oleh kata majemuk yang dimaksud, perhatikan kalimat berikut.

31) Badannya kurus kering.

32) Setiap hari ia pulang pergi ke tempat kerjanya.

Kalimat nomor (31) termasuk kalimat beraspek karena kalimat itu menggambarkan suatu peristiwa atau kejadian yang dinyatakan dengan kata majemuk kurus kering. Kata majemuk ini dibentuk dari unsur kurus dan kering. Proses pemajemukannya menimbulkan makna baru yaitu 'menyangatkan' atau menyatakan makna 'intensitas'. Dengan demikian, kata majemuk di atas dapat dikatakan menandai aspek intensitas.

Contoh:

31a) Rambutnya panjang dan berwarna hitam legam.

31b) Banyak sungai yang kering kerontang akibat musim kemarau.

Kalimat nomor (32) menggambarkan suatu peristiwa atau kejadian yang dinyatakan dengan kata majemuk pulang pergi. Kata majemuk ini dibentuk dari unsur pulang dan pergi sebagai unsurnya. Kedua unsurnya tersebut termasuk jenis kata kerja. Apabila dilihat dari aspeknya, peristiwa atau kejadian yang digambarkan dalam kalimat tersebut termasuk aspek yang tidak tentu. Artinya, mungkin peristiwa atau kejadian itu terjadi sekali, dilakukan berulangulang, atau menyatakan lainnya.

Uraian tentang kata majemuk di atas menunjukkan, bahwa tidak banyak kata majemuk yang dapat menandai jenis aspek tertentu. Hal ini terbukti hanya satu jenis aspek yang dapat ditandai oleh kata majemuk. Aspek yang dimaksud adalah aspek intensitas.

\section{SIMPULAN}

Berdasarkan uraian di atas, dapat dibuat simpulan sebagai berikut. Aspek dalam bahasa Indonesia dapat dibedakan menjadi beberapa jenis, sesuai dengan keadaan, peristiwa, dan proses yang digambarkan.

Berdasarkan hasil penelitian, dalam bahasa Indonesia ditemukan sepuluh jenis aspek. Kesepuluh jenis aspek itu adalah sebagai berikut.

1) Aspek duratif, yaitu aspek yang menyatakan suatu keadaan, peristiwa, dan 
proses yang sedang berlangsung atau sedang terjadi. Aspek ini juga disebut aspek inkompletif.

2) Aspek frekuentatif, yaitu aspek yang menyatakan suatu keadaan, peristiwa, dan proses yang terjadi beberapa kali secara terputus-putus. Atau dengan kata lain, aspek ini menggambarkan suatu peristiwa atau kejadian yang terjadi beberapa kali tetapi tidak terus-menerus.

3) Aspek inkoatif, yaitu aspek yang menyatakan suatu keadaan, peristiwa, dan proses yang mulai terjadi.

4) Aspek perfektif, yaitu aspek yang menyatakan suatu keadaan, peristiwa, dan proses yang telah terjadi atau sudah selesai.

5) Aspek futuratif, yaitu aspek yang menyatakan suatu keadaan, peristiwa, dan proses yang akan terjadi atau akan berlangsung.

6) Aspek iteratif, yaitu aspek yang menyatakan suatu keadaan, peristiwa, dan proses yang terjadi berulang-ulang tanpa putus-putus atau terus-menerus.

7) Aspek habituatif, yaitu aspek yang menyatakan suatu keadaan, peristiwa, dan proses yang terjadi karena kebiasaan.

8) Aspek momentan, yaitu aspek yang menyatakan suatu keadaan, peristiwa, dan proses yang terjadi sekali ataupun yang terjadi secara berturut-turut dalam waktu yang singkat atau sebentar.

9) Aspek spontanitas, yaitu aspek yang menyatakan suatu keadaan, peristiwa, dan proses yang terjadi secara tiba-tiba atau tanpa disangka-sangka.
10) Aspek indeterminatif, yaitu aspek yang menyatakan suatu keadaan, peristiwa, dan proses yang dilakukan secara santai, seenaknya, atau tanpa tujuan tertentu.

Secara morfologis menunjukkan, bahwa aspek dalam bahasa I ndonesia dapat ditandai dengan afiks, kata ulang dan kata majemuk. Afiks yang menandai jenis aspek tertentu adalah prefiks meN-, prefiks ter-, sufiks -kan, sufiks -I dan konfiks ber-an. Jenis aspek yang ditandai adalah aspek duratif, aspek perfektif, aspek spontanitas, dan aspek iteratif. Kata ulang dapat menandai jenis aspek tertentu adalah kata ulang yang bermakna "peristiwa seperti yang tersebut pada bentuk dasar dilakukan berulangulang dan terus menerus', perbuatan seperti yang tersebut pada bentuk dasar dilakukan secara santai dan seenaknya', dan kata ulang yang bermakna 'resiprokal'. Selanjunya, dalam kata majemuk aspek yang ditandai adalah aspek intensitas. Kata majemuk yang menandai jenis aspek ini adalah kata majemuk yang bermakna 'menyangatkan'.

\section{DAFTAR PUSTAKA}

Djayasoedarma, T. F. (1985) Aspek, Kala/Adverbia Temporal, dan Modus dalam Untaian Teori Sintaksis. Edited by Bambang Purwa. Jakarta: Arcan.

Halim, A. (1980) Politik Bahasa Nasional. Jakarta: PN. Balai Pustaka.

Mustakim (1994) Membina Kemampuan Berbahasa, Panduan ke arah kemarihan Berbahasa. Jakarta: PT Gramedia.

Ramlan. M (1983) Ilmu Bahasa Indonesia Morfologi. Yogyakarta: CV Karyono.

Samsuri (1985) nalisis Bahasa. Jakarta: Erlangga. 